\title{
ATP $\gamma$ S stalls splicing after B complex formation but prior to spliceosome activation
}

\author{
DMITRY E. AGAFONOV, ${ }^{1}$ MARIEKE VAN SANTEN, ${ }^{1,5}$ BERTHOLD KASTNER, ${ }^{1}$ PRAKASH DUBE, ${ }^{2}$ \\ CINDY L. WILL, ${ }^{1}$ HENNING URLAUB, ${ }^{3,4}$ and REINHARD LÜHRMANN ${ }^{1}$ \\ ${ }^{1}$ Department of Cellular Biochemistry, MPI for Biophysical Chemistry, D-37077 Göttingen, Germany \\ ${ }^{2} 3$ D Electron Cryomicroscopy Group, MPI for Biophysical Chemistry, D-37077 Göttingen, Germany \\ ${ }^{3}$ Bioanalytical Mass Spectrometry Group, MPI for Biophysical Chemistry, D-37077 Göttingen, Germany \\ ${ }^{4}$ Bioanalytics Group, Institute for Clinical Chemistry, University Medical Center Göttingen, D-37075 Göttingen, Germany
}

\begin{abstract}
The ATP analog ATP $\gamma$ S inhibits pre-mRNA splicing in vitro, but there have been conflicting reports as to which step of splicing is inhibited by this small molecule and its inhibitory mechanism remains unclear. Here we have dissected the effect of ATP $\gamma S$ on pre-mRNA splicing in vitro. Addition of ATP $\gamma$ S to splicing extracts depleted of ATP inhibited both catalytic steps of splicing. At ATP $\gamma$ S concentrations $\geq 0.5 \mathrm{mM}$, precatalytic B complexes accumulate, demonstrating a block prior to or during the spliceosome activation stage. Affinity purification of the ATP $\gamma S$-stalled B complexes $\left(B^{A T P \gamma S}\right)$ and subsequent characterization of their abundant protein components by $2 \mathrm{D}$ gel electrophoresis revealed that $\mathrm{B}^{\mathrm{ATP} \gamma \mathrm{S}}$ complexes are compositionally more homogeneous than B complexes previously isolated in the presence of ATP. In particular, they contain little or no Prp19/CDC5L complex proteins, indicating that these proteins are recruited after assembly of the precatalytic spliceosome. Under the electron microscope, $B^{\mathrm{ATP} \gamma \mathrm{S}}$ complexes exhibit a morphology highly similar to B complexes, indicating that the ATP $\gamma \mathrm{S}$-induced block in the transformation of the $B$ to $B^{\text {act }}$ complex is not due to a major structural defect. Likely mechanisms whereby ATP $\gamma S$ blocks spliceosome assembly at the activation stage, including inhibition of the RNA helicase Brr2, are discussed. Given their more homogeneous composition, B complexes stalled by ATP $\gamma \mathrm{S}$ may prove highly useful for both functional and structural analyses of the precatalytic spliceosome and its conversion into an activated $B^{\text {act }}$ spliceosomal complex.
\end{abstract}

Keywords: pre-mRNA splicing; spliceosome; small molecule; ATP $\gamma$ S; Prp19/CDC5L complex

\section{INTRODUCTION}

Pre-mRNA splicing is catalyzed by the spliceosome, a dynamic highly complex RNP machine. Assembly of the spliceosome occurs by the stepwise interaction of the U1, U2, U4/ U6, and U5 snRNPs, plus many additional non-snRNP proteins with the pre-mRNA (for review, see Wahl et al. 2009; Will and Lührmann 2011). The spliceosome carries out two successive transesterification reactions that lead to removal of an intron and the ligation of its flanking exons. Spliceosome assembly initiates by the ATP-independent association of U1 with the $5^{\prime}$ splice site (ss) and initial docking of the U2 snRNP, forming the spliceosomal E complex (Michaud and Reed 1991). Stable integration of the U2 snRNP via its interaction with the branch site (BS) of the pre-mRNA's intron, generates the A complex. The recruitment and stable integration of the U4/U6.U5 tri-snRNP to the spliceosome follows, yielding the precatalytic B complex

\footnotetext{
${ }^{5}$ Present address: NWO Chemical Sciences, NL-2509 AC The Hague, The Netherlands

Corresponding author: Reinhard.Luehrmann@mpi-bpc.mpg.de

Article published online ahead of print. Article and publication date are at http://www.rnajournal.org/cgi/doi/10.1261/rna.057810.116.
}

which does not yet have an active center. During the subsequent catalytic activation of the spliceosome, which generates the $\mathrm{B}^{\text {act }}$ complex, the extensively base paired U4/U6 snRNAs are unwound, thereby releasing $\mathrm{U} 4$ and allowing the formation of new U2/U6 base-pairing interactions and a catalytically important U6 internal stem-loop (ISL) (Valadkhan 2013). Concomitant with or prior to this, the base-pairing interaction between the pre-mRNA's 5'ss and the U1 snRNA must be disrupted, in order to allow base-pairing between U6's highly conserved ACAGA sequence and the $5^{\prime}$ end of the intron (Staley and Guthrie 1998). This newly formed U2-U6pre-mRNA RNA interaction network comprises the catalytic centre of the spliceosome (Valadkhan 2013). After additional RNP rearrangements, the catalytically active $B^{*}$ complex forms and catalyzes the first transesterification reaction of splicing. This involves cleavage at the 5 'ss and ligation of

\footnotetext{
(C) 2016 Agafonov et al. This article is distributed exclusively by the RNA Society for the first 12 months after the full-issue publication date (see http://rnajournal.cshlp.org/site/misc/terms.xhtml). After 12 months, it is available under a Creative Commons License (Attribution-NonCommercial 4.0 International), as described at http://creativecommons.org/licenses/ by-nc/4.0/.
} 
the $5^{\prime}$ end of the intron to the branch site, and generates the splicing intermediates, the excised $5^{\prime}$ exon and the lariatshaped intron-3'exon. The subsequently formed C complex then catalyzes the second transesterification reaction of splicing, involving excision of the intron and ligation of the $5^{\prime}$ and $3^{\prime}$ exon to form the mRNA.

Over 170 proteins are associated at one time or another with the human splicing machinery and there is a dramatic exchange of proteins during the transitions from one spliceosomal complex to the next (Wahl et al. 2009; Wahl and Lührmann 2015). Our knowledge about the spliceosome's highly complex compositional dynamics is, however, hampered by the limited number of distinct spliceosomal complexes that can be biochemically detected or isolated. Given the extensive exchange of proteins during the transitions from the $\mathrm{B}$ to $\mathrm{B}^{\text {act }}$, and $\mathrm{B}^{\text {act }}$ to $\mathrm{C}$ complex, there are likely to be numerous additional, intermediate assembly stages in which only a subset of these proteins are released or recruited. Currently, many preparations of purified human spliceosomal complexes likely consist of a mixture of assembly stages, which prevents a clear picture of when some spliceosomal proteins are first recruited during assembly. To overcome this problem, small molecule inhibitors of splicing have more recently been used with the hope of obtaining more homogeneous populations of splicing complexes by stalling splicing at a highly specific stage (Kuhn et al. 2009; Berg et al. 2012; Effenberger et al. 2013, 2015; Pawallek et al. 2015).

ATP is required for each step of spliceosome assembly/ disassembly and the catalytic steps of splicing, except for the association of $\mathrm{U} 1$ and $\mathrm{U} 2$ during the earliest stage of spliceosome assembly (i.e., E complex formation). However, the transesterification reactions per se do not consume ATP. At least eight conserved ATP-dependent $\mathrm{DExD} / \mathrm{H}-$ box RNA/RNP remodeling enzymes drive the multiple rearrangements of the spliceosome during its working cycle and account for the ATP dependence of most structural rearrangements (Cordin and Beggs 2013; Liu and Cheng 2015). The DEAD-box helicases Sub2 and Prp5 are required for stable U2 snRNP integration during A complex assembly. During B complex formation, the DEAD-box protein Prp28 catalyzes the exchange of U1 with U6 at the 5'ss (Staley and Guthrie 1999), and during the transition from complex B to $\mathrm{B}^{\text {act }}$, the $\mathrm{DExD} / \mathrm{H}$-box protein $\mathrm{Brr} 2$ of the Ski-2 helicase family catalyzes a key step in spliceosome activation, namely the unwinding of U4/U6 snRNA (Laggerbauer et al. 1998; Raghunathan and Guthrie 1998). The DExH/D-box protein Prp2 promotes an RNP remodeling event that converts $\mathrm{B}^{\text {act }}$ into the catalytically active $\mathrm{B}^{*}$ complex (Kim and Lin 1996; Warkocki et al. 2009; Lardelli et al. 2010). The remaining DExD/H-box proteins Prp16, Prp22 and Prp43 promote conformational rearrangements during the catalytic steps of splicing and/or are involved in spliceosome disassembly (for review, see Cordin and Beggs 2013; Liu and Cheng 2015).
ATP is required not only for the ATPases/RNA helicases that drive the conformational rearrangements in the spliceosome, but also for the many kinases and phosphatases involved in the phosphorylation/dephosphorylation of numerous spliceosomal proteins. For example, SR protein phosphorylation/dephosphorylation is essential for premRNA splicing (for review, see Misteli 1999; Soret and Tazi 2003), with SR protein phosphorylation shown to be required during spliceosome assembly (Mermoud et al. 1994; Xiao and Manley 1997). Dephosphorylation of several spliceosomal phosphoproteins is required for the catalytic steps of splicing, with PP1/PP2A phosphatases playing key roles at this stage (Mermoud et al. 1992; Shi et al. 2006).

The small molecule ATP analog ATP $\gamma$ S has been used to study the requirement for protein dephosphorylation during splicing, as thiophosphorylated proteins are poorly dephosphorylated by protein phosphatases ( $\mathrm{Li}$ et al. 1988). Kinases can use ATP $\gamma S$ to thiophosphorylate proteins, making them resistant to rapid dephosphorylation. ATP $\gamma \mathrm{S}$ can be hydrolyzed by some enzymes but usually at a much lower rate compared with ATP (Yount 1975). Addition of ATP $\gamma$ S to in vitro splicing reactions was initially reported to stall splicing during the second catalytic step (Tazi et al. 1992). In contrast, subsequent studies indicated that thiophosphorylation of the U1-70K protein (Tazi et al. 1993) or SR proteins (Cao et al. 1997), which were added back to nuclear or S100 extract lacking these proteins, blocked splicing prior to the first step of splicing, but after the B complex stage. However, the precise stage at which spliceosome assembly is blocked was not clear.

Here we have analyzed the effect of ATP $\gamma \mathrm{S}$ on splicing in vitro, and characterized the composition and structure of splicing complexes that accumulate in the presence of ATP $\gamma$ S. Our studies indicate that ATP $\gamma S$ blocks splicing just prior to the action of Brr2, at a stage after B complex formation but prior to U4/U6 unwinding during spliceosome activation. In contrast to previous preparations of the human B complex, which consist of a mixture of assembly states due to the fact that they are kinetically stalled, B complexes that accumulate in the presence of ATP $\gamma S$ are essentially devoid of Prp19/CDC5L complex proteins and thus more homogeneous. Thus, our data indicate that highly pure B complexes lack the latter proteins and therefore that the hPrp19/CDC5 proteins first interact during $\mathrm{B}^{\text {act }}$ formation, after/concomitant with dissociation of U4. Taken together, our data also reveal that ATP $\gamma S$ can be used as an efficient small molecule inhibitor of splicing to generate spliceosomal complexes stalled at a very specific stage of the assembly process.

\section{RESULTS AND DISCUSSION}

To elucidate its effect on pre-mRNA splicing in vitro, we added increasing amounts of ATP $\gamma$ S to a splicing reaction containing HeLa nuclear extract and ${ }^{32} \mathrm{P}$-labeled MINX premRNA with MS2 aptamers for affinity purification (Fig. 1). 
A

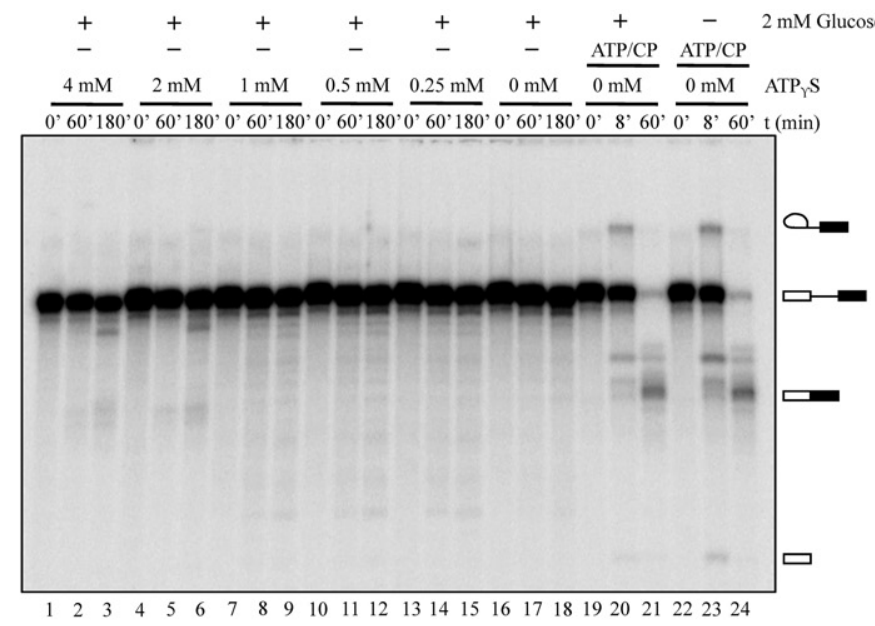

C

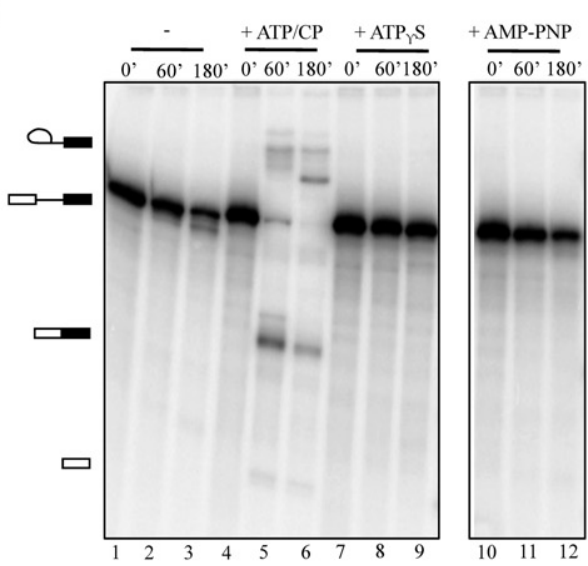

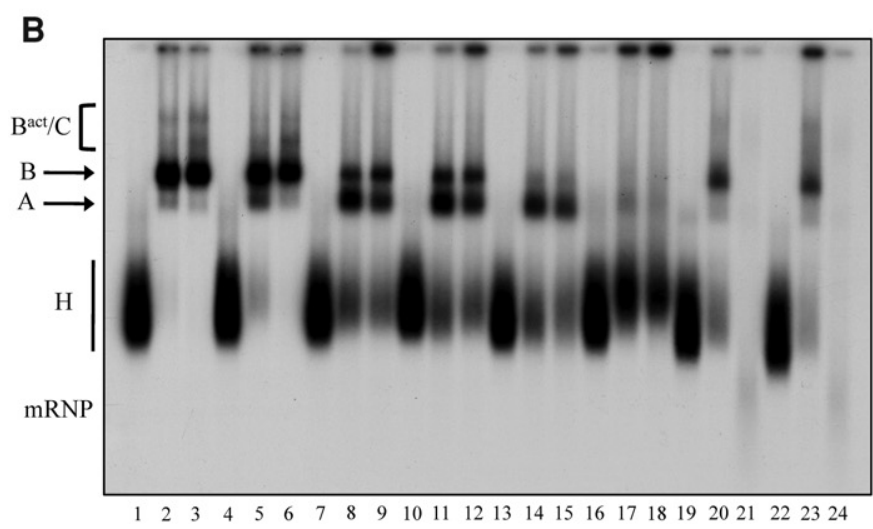

D
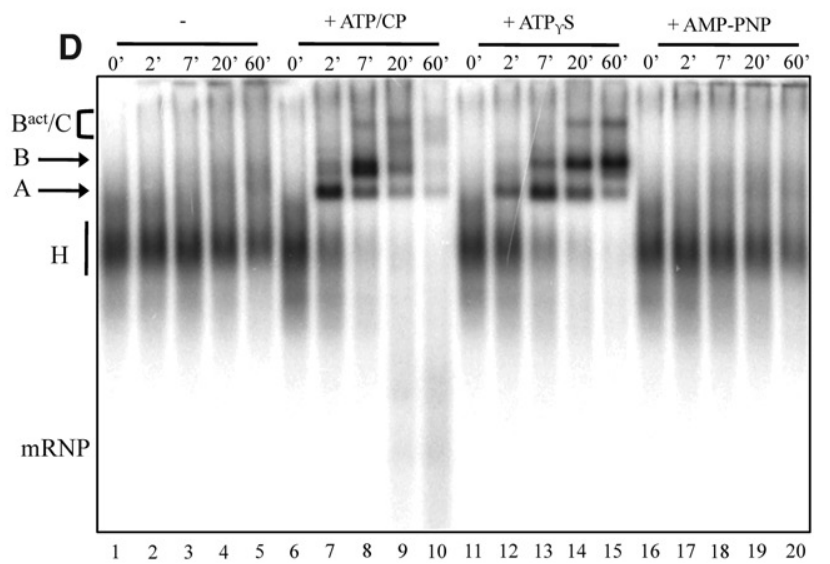

FIGURE 1. ATP $\gamma S$ blocks spliceosome assembly before catalytic activation. (A) In vitro splicing of ${ }^{32} \mathrm{P}$-labeled MINX pre-mRNA was performed for the indicated times in untreated HeLa nuclear extract (lanes 22-24) or extract depleted of ATP by incubating with $2 \mathrm{mM}$ glucose (lanes 1-21). Splicing was carried out in the presence of $2 \mathrm{mM}$ ATP and creatine phosphate ATP/CP (lanes 19-24) or in the presence of increasing concentrations of ATP $\gamma \mathrm{S}$ (in the absence of ATP) as indicated above (lanes 1-18). Splicing was analyzed by denaturing PAGE and the positions of the pre-mRNA substrate and intermediates/products of the splicing reaction are shown on the right. The spliced out lariat has been debranched and thus is not visible above the unspliced pre-mRNA. $(B)$ In vitro splicing was performed as in $A$, and the formation of splicing complexes was analyzed on a native agarose gel. The positions of the splicing complexes ( $\mathrm{A}, \mathrm{B}, \mathrm{B}$ act, and $\mathrm{C}$ ), as well as the $\mathrm{H}$ complex, are indicated on the left. $(C)$ In vitro splicing as in $A$, performed in ATP-depleted extract (lanes 1-3) or ATP-depleted extract supplemented with $2 \mathrm{mM} \mathrm{ATP}$ and CP (lanes 4-6), 2 mM ATP $\gamma \mathrm{S}$ (lanes 7-9), or 2 mM AMP-PNP (lanes 10-12) for 0-180 min as indicated above. (D) Analysis of splicing complex formation (as in B) in the absence of ATP (lanes 1-5) or in its presence (ATP/CP, lanes 6-10) or in the presence of $2 \mathrm{mM} \mathrm{ATP} \gamma \mathrm{S}$ (lanes 11-15) or AMP-PNP (lanes 16-20). Splicing was performed for 0-60 min as indicated above each lane.

The extract was first depleted of ATP by preincubating with 2 $\mathrm{mM}$ glucose for $30 \mathrm{~min}$ at $30^{\circ} \mathrm{C}$ (Michaud and Reed 1991), which abolished both steps of splicing (Fig. 1A, compare lanes 16-18 with 19-21 where ATP/creatine phosphate, CP, were subsequently added), and inhibited splicing complex formation (Fig. 1B). Both catalytic steps of splicing were completely inhibited at all concentrations of ATP $\gamma \mathrm{S}$ tested $(0.25-4.0 \mathrm{mM}$ ), even after incubating for $3 \mathrm{~h}$ (Fig. 1A) or 6 $\mathrm{h}$ (data not shown). Addition of low concentrations (0.25$1.0 \mathrm{mM}$ ) of ATP $\gamma \mathrm{S}$ led to an accumulation of A complexes, whereas at higher concentrations spliceosomal complexes migrating like a B complex accumulated (Fig. 1B). The accumulation of $B$ complexes was specific for ATP $\gamma$ S, as the addition of the nonhydrolyzable AMP-PNP, which also inhibited splicing completely, abolished both A and B complex forma- tion at $2 \mathrm{mM}$ (Fig. 1C, lanes 10-12 and Fig. 1D, lanes 16-20). These results suggest that the accumulation of precatalytic splicing complexes in the presence of ATP $\gamma S$ results either from the thiophosphorylation of one or more spliceosomal proteins or the inhibition of one or more ATP-dependent enzymes involved in the splicing process. Previous studies indicated that ATP $\gamma \mathrm{S}$ blocks in vitro splicing first during the catalytic steps of splicing (Tazi et al. 1992). However, the splicing reactions performed by Tazi and colleagues contained creatine phosphate (CP) in addition to ATP $\gamma S$; thus most of the hydrolyzed ATP analog could be regenerated to ATP, which could explain why their splicing reactions were not blocked at an earlier stage similar to ours. Indeed, thiophosphorylation of U1-70K, which would occur under our conditions, was shown to block splicing prior to step 1 but 
after assembly of the spliceosome (Tazi et al. 1993), consistent with ATP $\gamma \mathrm{S}$ affecting splicing before the catalytic steps.

\section{Affinity purification of A complexes stalled with ATP $\gamma$ S}

To characterize the spliceosomal complexes stalled by ATP $\gamma \mathrm{S}$ in more detail we affinity purified them by MS2 affinity selection. Complexes were assembled in splicing extract depleted of ATP and supplemented with $0.4 \mathrm{mM}$ (for isolation of A complexes) or $2 \mathrm{mM} \mathrm{ATP} \gamma \mathrm{S}$ for the isolation of stalled B complexes. Splicing complexes were purified from the splicing reaction by MS2 affinity selection and then subjected to glycerol gradient centrifugation.

Two main peaks were observed in the presence of $0.4 \mathrm{mM}$ ATP $\gamma \mathrm{S}$ (Fig. 2A). The faster migrating peak contained complexes with equimolar amounts of the MINX pre-mRNA and U1 and U2 snRNPs as evidenced by their RNA composition (Fig. 2B), indicating that they are spliceosomal A complexes. Proteins of these affinity-purified complexes were
A

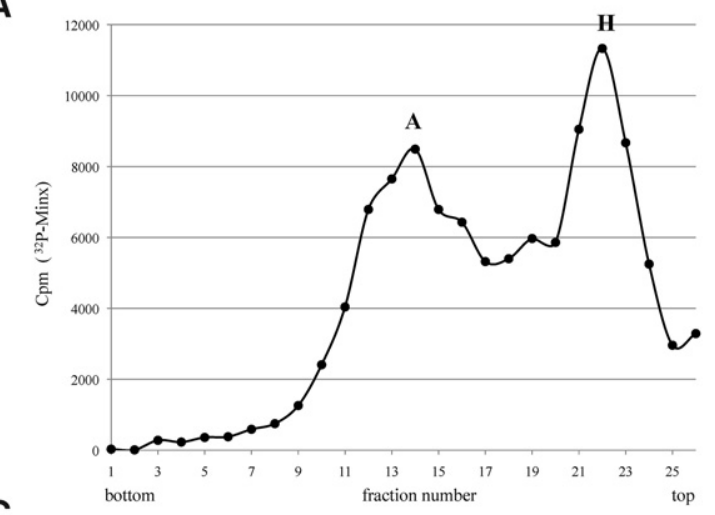

C

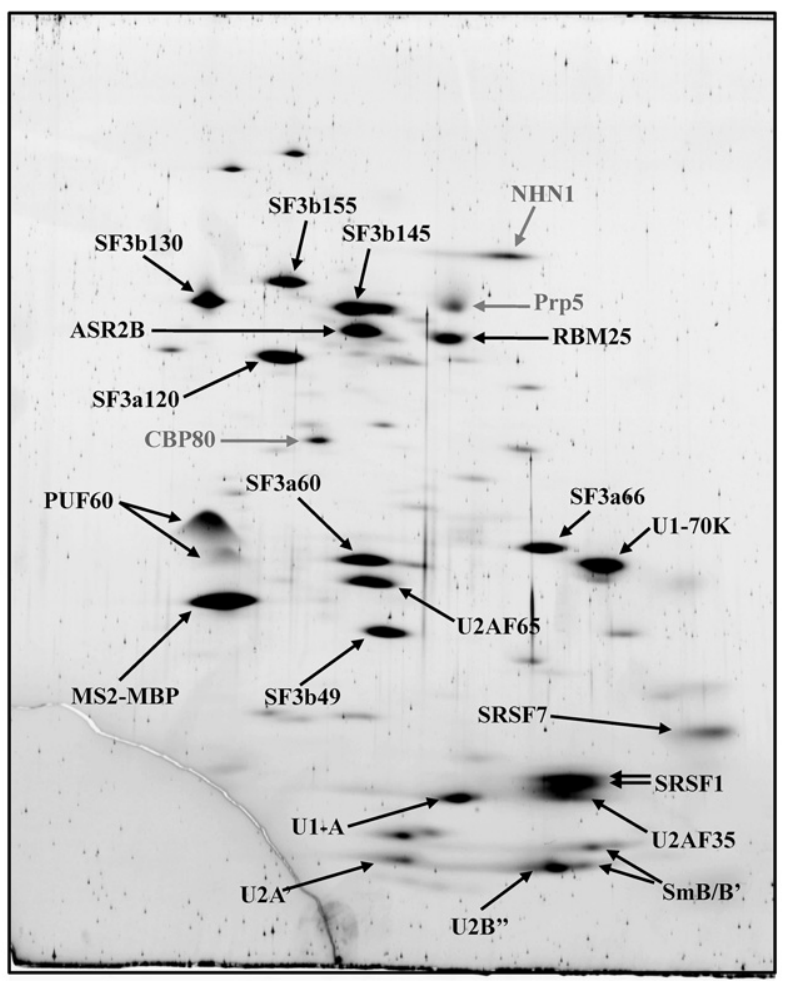

B

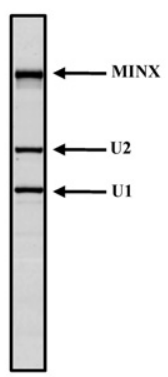

D

\begin{tabular}{|c|c|c|c|c|}
\hline $\begin{array}{c}\text { Protein } \\
\text { name }\end{array}$ & $\begin{array}{c}\text { gene } \\
\text { name }\end{array}$ & $\begin{array}{l}\text { MW } \\
\text { kDa }\end{array}$ & gi I number & $\begin{array}{l}S \text {. cerevisiae } \\
\text { gene name }\end{array}$ \\
\hline \multicolumn{5}{|l|}{$\underline{\text { Sm proteins }}$} \\
\hline $\mathrm{SmB} / \mathbf{B}^{\prime}$ & $S N R P B$ & 24.6 & gi|119631003 & $S M B 1$ \\
\hline \multicolumn{5}{|l|}{ U1 snRNP } \\
\hline U1-70K & SNRNP70 & 51.6 & gi|29568103 & $S N P 1$ \\
\hline U1-A & SNRPA & 31.3 & gi||189053747 & MUD1 \\
\hline \multicolumn{5}{|l|}{ U2 snRNP } \\
\hline $\begin{array}{l}\mathbf{U}^{2} \mathbf{A}^{\prime} \\
\end{array}$ & SNRPAI & 28.4 & gi|50593002 & LEAI \\
\hline U2B" & SNRPB2 & 25.4 & gi|119630691 & MSL1 \\
\hline SF3a120 & $S F 3 A 1$ & 88.9 & gi|5032087 & PRP21 \\
\hline SF3a66 & $S F 3 A 2$ & 49.3 & gi||116283242 & PRP11 \\
\hline SF3a60 & $S F 3 A 3$ & 58.5 & gi |158255798 & PRP9 \\
\hline SF3b155 & $S F 3 B 1$ & 145.8 & gi|54112117 & HSH155 \\
\hline SF3b145 & $S F 3 B 2$ & 100.2 & gi|33875399 & CUS1 \\
\hline SF3b130 & $S F 3 B 3$ & 135.5 & gi|54112121 & RSE1 \\
\hline SF3b49 & $S F 3 B 4$ & 44.4 & gi $\mid 5032069$ & HSH49 \\
\hline \multicolumn{5}{|c|}{ U2 snRNP related } \\
\hline U2AF65 & $U 2 A F 2$ & 53.5 & gi $\mid 6005926$ & MUD2 \\
\hline U2AF35 & $U 2 A F 1$ & 27.9 & gi $\mid 5803207$ & \\
\hline PUF60 & PUF60 & 59.9 & gi|17298690 & \\
\hline \multicolumn{5}{|l|}{ RNA binding } \\
\hline ASR2B & SRRT & 101 & gi|20137457 & \\
\hline RBM25 & RBM25 & 100.1 & gi||219520438 & \\
\hline \multicolumn{5}{|l|}{$\underline{\text { SR proteins }}$} \\
\hline SRSF1 & SRSF1 & 27.8 & gi|5902076 & \\
\hline SRSF7 & SRSF7 & 27.4 & gi|72534660 & \\
\hline
\end{tabular}

FIGURE 2. Affinity purification of A complexes accumulating in the presence of ATP $\gamma \mathrm{S}$. (A) Splicing complexes were allowed to form on ${ }^{32} \mathrm{P}-\mathrm{MINX}$ pre-mRNA containing MS2 aptamers bound by MS2-MBP protein, in HeLa nuclear extract containing $0.4 \mathrm{mM}$ ATP $\gamma$ S. Complexes were subsequently affinity purified on an amylose column and the eluate subjected to glycerol gradient centrifugation in buffer containing $150 \mathrm{mM} \mathrm{NaCl}$. The number of $\mathrm{cpm}$ in each gradient fraction is plotted. (B) RNA composition of complexes in the faster migrating peak (fraction \#13). (C) Proteins from affinitypurified A complexes formed in the presence of ATP $\gamma S$ (fractions \#13-14) were separated by 2D gel electrophoresis, stained with RuBPS, and the identities of protein spots were determined by mass spectrometry. Proteins smaller than $25 \mathrm{kDa}$ were not analyzed. Abundant proteins are indicated in black and less abundant ones in gray. $(D)$ Summary of abundant/moderately abundant proteins identified in $\mathrm{A}^{\text {ATP } \gamma \mathrm{S}}$ complexes. 
subsequently analyzed by 2D gel electrophoresis followed by mass spectrometry (MS) to identify abundant components (Fig. 2C,D). Abundant or moderately abundant proteins (with a molecular mass above $25 \mathrm{kDa}$ ) in the A complexes stalled by ATP $\gamma \mathrm{S}$ (henceforth denoted $\mathrm{A}^{\mathrm{ATP} \gamma \mathrm{S}}$ ) included: (i) all $12 \mathrm{~S} \mathrm{U} 1$ and $17 \mathrm{~S} \mathrm{U} 2$ proteins, (ii) the $17 \mathrm{~S} \mathrm{U} 2$-related proteins U2AF65, U2AF35, and PUF60, which bind the polypyrimidine tract, (iii) the SR proteins SRSF1 and SRSF7, (iv) ASR2B and finally S164/RBM25 (RNA-binding motif protein 25 ), which was shown to regulate the alternative splicing of the apoptotic factor $\mathrm{Bcl}-\mathrm{x}$ pre-mRNA by promoting the recruitment of U1 snRNP to a weak 5'ss (Zhou et al. 2008). A highly similar set of abundant proteins was detected in affinity-purified A complexes formed in the presence of ATP (Agafonov et al. 2011). Thus, complexes with a protein composition generally characteristic for the A complex can be assembled with ATP $\gamma S$ as the sole energy source and these $\mathrm{A}^{\text {ATP } \gamma \mathrm{S}}$ complexes support efficient B complex formation if the concentration of ATP $\gamma \mathrm{S}$ is above $\sim 0.25 \mathrm{mM}$ (Fig. 1B).

Phosphorylation of SR proteins is required for spliceosome assembly (Zhou and Fu 2013), and these results indicate that thio-phosphorylated SR (and other proteins) are still functional at this stage, consistent with previous observations (Tazi et al. 1993; Cao et al. 1997). Our results also indicate that low concentrations of ATP $\gamma S$ are sufficient for Prp5 and Sub2 activity at this stage of spliceosome assembly, consistent with a requirement for ATP binding, rather than ATP hydrolysis (or at least rapid hydrolysis) for their function in splicing. Indeed, DEAD-box proteins often can act after binding ATP (even without hydrolyzing it), which leads to a conformational change in the DEAD-box protein that can alter the local structure of bound RNA/RNPs (Cordin and Beggs 2013).

\section{Characterization of B complexes formed in the presence of $\mathrm{ATP} \gamma \mathrm{S}$}

After MS2 affinity selection and subsequent glycerol gradient centrifugation, two peaks with S-values of $\sim 40 \mathrm{~S}$ and $\sim 60 \mathrm{~S}$ were consistently observed at an ATP $\gamma S$ concentration of 2 $\mathrm{mM}$ (Fig. 3A), where predominantly B complexes were observed on native agarose gels (Fig. 1B). The RNA composition of fractions comprising each peak was subsequently analyzed and revealed an identical snRNA composition. That is, complexes peaking in both regions of the gradient contained equimolar amounts of U2, U4, U5, U6, and MINX RNA, but almost no U1 snRNA, similar to affinity-purified $\mathrm{B}$ complexes generated by incubating the splicing reaction for 5-7 min (Agafonov et al. 2011). Analysis of the protein composition of the $40 \mathrm{~S}$ and $60 \mathrm{~S}$ complexes revealed a very similar protein composition (data not shown); thus, the faster migrating peak likely contains dimers of the $\mathrm{B}$ complexes that accumulate in the presence of ATP $\gamma$ S.

Abundant proteins present in the monomeric $\mathrm{B}$ complexes stalled in the presence of $\mathrm{ATP} \gamma \mathrm{S}$ (denoted $\mathrm{B}^{\mathrm{ATP} \gamma \mathrm{S}}$ ) were determined by 2D gel electrophoresis followed by mass spectrometry (MS) (Fig. 3C,D). Abundant or moderately abundant proteins (with a molecular mass above $25 \mathrm{kDa}$ ) in the $\mathrm{B}^{\mathrm{ATP} \gamma \mathrm{S}}$ complexes included: (i) nearly all $17 \mathrm{~S}$ U2, U5, and U4/U6 snRNP proteins, (ii) the tri-snRNP-specific proteins Snu66/110K and Sad1/65K, (iii) the so-called B-specific proteins hSmu1, MFAP1, RED, hSnu23, hPrp38, and FBP21, (iv) the Prp19 complex related proteins NPW38 and NPW38BP, (v) the 17S U2-related proteins U2AF65, U2AF35 and, as well as the DEXH-box protein Prp43, and (vi) the SR proteins SRSF1 and SRSF7. A very similar set of abundant proteins was previously reported for B complexes formed in the presence of ATP (Agafonov et al. 2011).

However, unlike kinetically stalled B complexes, $B^{\text {ATP } \gamma \mathrm{S}}$ complexes contained little or no proteins of the Prp19/ CDC5L complex or Prp19-related proteins; only a low level of the Prp19 protein that is normally present in four copies in the $\mathrm{B}^{\text {act }}$ spliceosome was detected by $2 \mathrm{D}$ gel electrophoresis (Fig. 3C). Thus, $\mathrm{B}^{\mathrm{ATP} \gamma \mathrm{S}}$ complexes appear to have a much more homogeneous protein composition than previously reported B complexes. Indeed, kinetically stalled B complexes (i.e., isolated after incubating for a defined period of time) most certainly contain a mixture of different assembly states of the spliceosome, leading to both compositional and structural heterogeneity. The near absence of Prp19/CDC5L proteins suggests that the vast majority of $\mathrm{B}^{\mathrm{ATP} \gamma \mathrm{S}}$ complexes are stalled at a single assembly stage (i.e., prior to the docking/ stable integration of the Prp19/CDC5L complex proteins) and/or that the presence of thiophosphorylated spliceosomal proteins potentially inhibits the incorporation of Prp19/ CDC5L complex proteins. In addition, our data indicate that the Prp19/CDC5L complex proteins are not required for the formation of $\mathrm{B}$ complexes that withstand gel electrophoresis in the presence of heparin (Fig. 1B) (i.e., highly stable B complexes), consistent with data showing the formation of heparin-resistant B complexes in extracts depleted of the Prp19/CDC5L complex (Makarova et al. 2004). Although proteins of the hPrp19/CDC5 complex are present in kinetically stalled B complexes, they are first enriched and stably associated in the spliceosomal $\mathrm{B}^{\text {act }}$ complex (Bessonov et al. 2010). Our data indicate that highly pure B complexes in fact do not contain these proteins and that the hPrp19/ $\mathrm{CDC} 5$ proteins first interact during $\mathrm{B}^{\text {act }}$ formation, after/concomitant with dissociation of $\mathrm{U} 4$.

\section{Structural characterization of the $\mathrm{B}^{\mathrm{ATP} \gamma \mathrm{S}}$ complex by EM}

To determine whether ATP $\gamma S$ affects the structure of the B complexes that accumulate in its presence, we performed negative-stain electron microscopy (EM). Well-defined, single particles of similar shape and size were visible in the EM overview of the monomeric $B^{\mathrm{ATP} \gamma \mathrm{S}}$ complexes (Fig. 4A). Classification and class averaging of more than 10,000 single particle images revealed a triangular body comprised of a stump, a central mass and a foot, and an upper (head) 
A

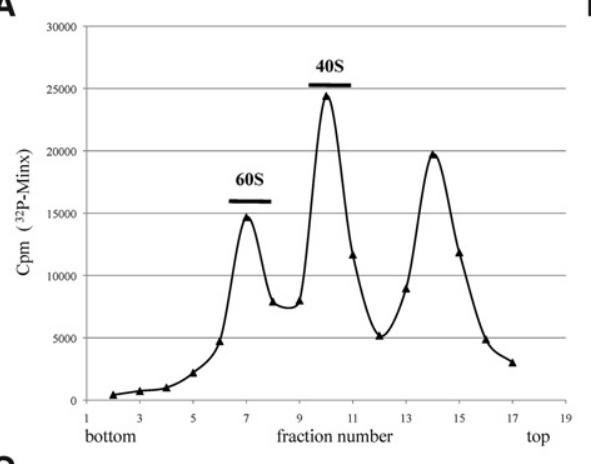

C

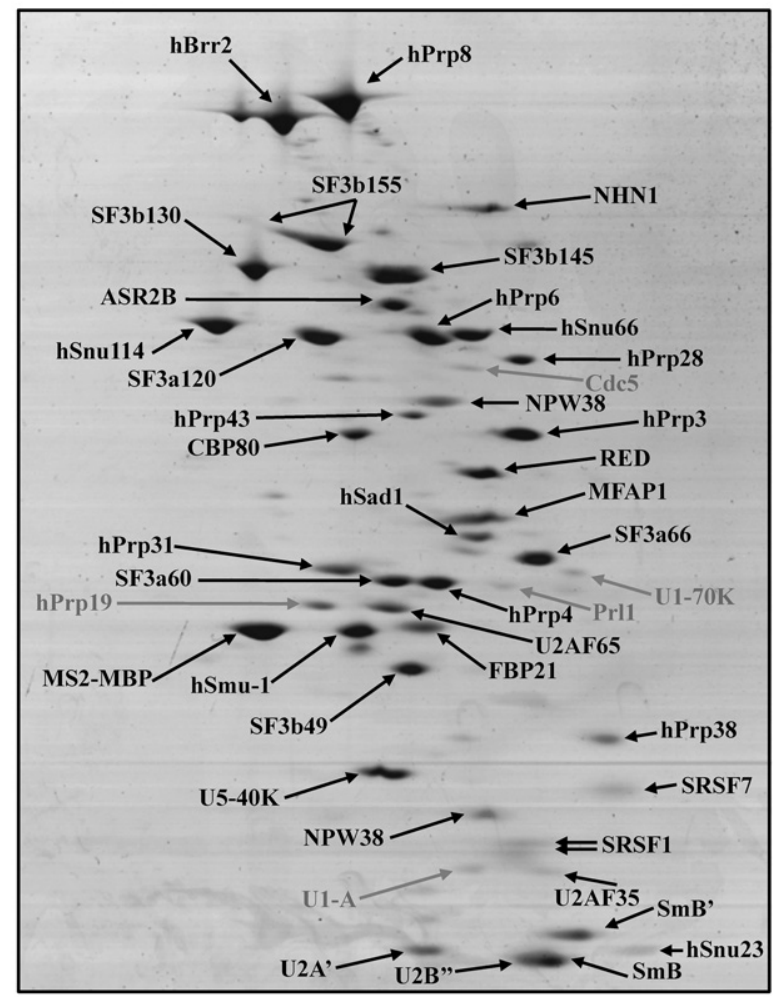

B

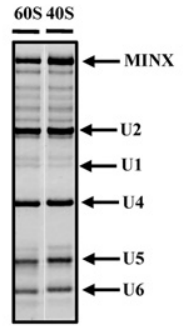

D

\begin{tabular}{|c|c|c|c|c|}
\hline $\begin{array}{c}\begin{array}{c}\text { Protein } \\
\text { name }\end{array} \\
\text { Sm proteins }\end{array}$ & $\begin{array}{l}\text { gene } \\
\text { name }\end{array}$ & $\begin{array}{l}\text { MW } \\
\text { kDa }\end{array}$ & gi I number & $\begin{array}{l}\text { S. cerevisiae } \\
\text { gene name }\end{array}$ \\
\hline $\mathrm{SmB} / \mathbf{B}^{\prime}$ & $S N R P B$ & 24.6 & gi|119631003 & SMB1 \\
\hline \multicolumn{5}{|l|}{ U2 snRNP } \\
\hline U2A' & SNRPAI & 28.4 & $\begin{array}{l}\text { gi } \mid 50593002 \\
\text { gil119630691 }\end{array}$ & LEA1 \\
\hline U2B" & SNRPB2 & 25.4 & gi|119630691 & MSL1 \\
\hline SF3a120 & $S F 3 A 1$ & 88.9 & gi $\mid 5032087$ & PRP21 \\
\hline SF3a66 & $S F 3 A 2$ & 49.3 & gi|116283242 & PRP11 \\
\hline SF3a60 & $S F 3 A 3$ & 58.5 & gi|158255798 & PRP9 \\
\hline SF3b155 & $S F 3 B 1$ & 145.8 & gi|54112117 & HSH155 \\
\hline SF3b145 & $S F 3 B 2$ & 100.2 & gi|33875399 & CUS1 \\
\hline SF3b130 & $S F 3 B 3$ & 135.5 & gi|54112121 & RSEI \\
\hline SF3b49 & $S F 3 B 4$ & 44.4 & gi|5032069 & HSH49 \\
\hline \multicolumn{5}{|c|}{ U2 snRNP related } \\
\hline U2AF65 & $U 2 A F 2$ & 53.5 & gi|6005926 & MUD2 \\
\hline U2AF35 & $U 2 A F 1$ & 27.9 & gi|5803207 & \\
\hline hPrp43 & DHX15 & 91 & gi|68509926 & PRP43 \\
\hline \multicolumn{5}{|l|}{ RNA binding } \\
\hline ASR2B & SRRT & 101 & gi|20137457 & \\
\hline NHN1 & ZC3H18 & 109 & gi $\mid 255652953$ & \\
\hline \multicolumn{5}{|l|}{ CAP binding } \\
\hline CBP80 & $N C B P I$ & 91.8 & gi $\mid 4505343$ & STO1 \\
\hline \multicolumn{5}{|l|}{ U5 snRNP } \\
\hline hPrp8 & PRPF8 & 273.7 & gi $\mid 91208426$ & PRP8 \\
\hline hBrr2 & SNRNP200 & 244.5 & gi|40217847 & $B R R 2$ \\
\hline hSnu114 & EFTUD2 & 109.4 & gi|12803113 & SNU114 \\
\hline hPrp6 & PRPFG & 106.9 & gi|189067252 & PRP6 \\
\hline hPrp28 & $D D X 23$ & 95.6 & gi|193785886 & PRP28 \\
\hline U5-40K & SNRNP40 & 39.3 & gi|115298668 & \\
\hline \multicolumn{5}{|l|}{ U4/U6 snRNP } \\
\hline hPrp3 & PRPF3 & 77.6 & gi $\mid \mathbf{4 7 5 8 5 5 6}$ & PRP3 \\
\hline hPrp31 & PRPF31 & 55.4 & gi|221136939 & PRP31 \\
\hline hPrp4 & PRPF4 & 58.4 & gi|189053699 & PRP4 \\
\hline \multicolumn{5}{|c|}{ U4/U6.U5 snRNP } \\
\hline hSnu66 & SARTI & 90.2 & gi|10863889 & SNU66 \\
\hline hSad1 & USP39 & 65.4 & gi|13926071 & $S A D 1$ \\
\hline \multicolumn{5}{|l|}{ Prp19-related } \\
\hline NPW38 & $P Q B P 1$ & 30.5 & gi|74735456 & \\
\hline NPW38BP & WBP11 & 67 & gi|1943788 & \\
\hline \multicolumn{5}{|c|}{ B complex-specific } \\
\hline RED & $I K$ & 65.6 & gi|125988409 & \\
\hline MFAP1 & MFAPI & 51.9 & gi $\mid 50726968$ & \\
\hline hSmu-1 & $S M U 1$ & 57.5 & gi|109948304 & \\
\hline FBP21 & WBP4 & 42.5 & gi|189069453 & \\
\hline hPrp38 & PRPF38A & 37.5 & gi|24762236 & PRP38 \\
\hline hSnu23 & ZMAT2 & 23.6 & gi|21389511 & $S N U 23$ \\
\hline \multicolumn{5}{|l|}{ SR proteins } \\
\hline SRSF1 & SRSFI & 27.8 & gi|5902076 & \\
\hline SRSF7 & SRSF7 & 27.4 & gi $\mid 72534660$ & \\
\hline
\end{tabular}

FIGURE 3. Affinity purification of B complexes accumulating in the presence of ATP $\gamma \mathrm{S}$. (A) Splicing complexes were allowed to form on ${ }^{32} \mathrm{P}-\mathrm{MINX}$ pre-mRNA containing MS2 aptamers bound by MS2-MBP protein, in HeLa nuclear extract containing $2.0 \mathrm{mM}$ ATP $\gamma$ S. Complexes were subsequently affinity purified on an amylose column and the eluate subjected to glycerol gradient centrifugation. $(B)$ RNA composition of complexes migrating in the $60 \mathrm{~S}$ and $40 \mathrm{~S}$ peaks. $(C)$ Proteins from ATP $\gamma \mathrm{S}$ stalled complexes in the $40 \mathrm{~S}$ gradient peak were separated by $2 \mathrm{D}$ gel electrophoresis, stained with Coomassie G-250, and the identities of protein spots were determined by mass spectrometry. $(D)$ Summary of abundant/moderately abundant proteins present in monomeric $\mathrm{B}^{\mathrm{ATP} \gamma \mathrm{S}}$ complexes.

domain, which are connected via a slimmer neck domain (Fig. 4B,D). The overall structure of the $\mathrm{B}^{\mathrm{ATP} \gamma \mathrm{S}}$ complexes is indistinguishable from $B$ complexes formed in the presence of ATP (Fig. 4C). Like wild-type, affinity-purified B complexes, almost identical views are seen in all class averages, indicating that the $\mathrm{B}^{\mathrm{ATP} \gamma \mathrm{S}}$ complexes bind in a highly preferential orientation to the carbon film. Taken together these data indicate that the presence of ATP $\gamma \mathrm{S}$ has little or no effect on the structural organization of the $\mathrm{B}$ complex. Thus, the ATP $\gamma S$-induced block in the transformation of the $B$ to $B^{\text {act }}$ complex, leading to accumulation of $B$ complexes, does not appear to be due to a major structural defect.
Our data indicate that B complex formation is not hindered if ATP $\gamma S$ is the sole source of energy in the in vitro splicing reaction, and is present at sufficient concentrations (i.e., $>0.25 \mathrm{mM}$ ). The requirement for a higher concentration of ATP $\gamma$ S for B versus A complex formation may reflect the different ATP $\gamma$ affinities of those enzymes required at each of these spliceosome assembly stages. The conversion of an A to $\mathrm{B}$ complex requires the action of the DEAD-box helicase Prp28, which exchanges U1 for U6 at the 5'ss (Staley and Guthrie 1999; Mathew et al. 2008). Phosphorylation of hPrp28 by the kinase SRPK2 also is required for B complex formation (Mathew et al. 2008). The tri-snRNP associated 


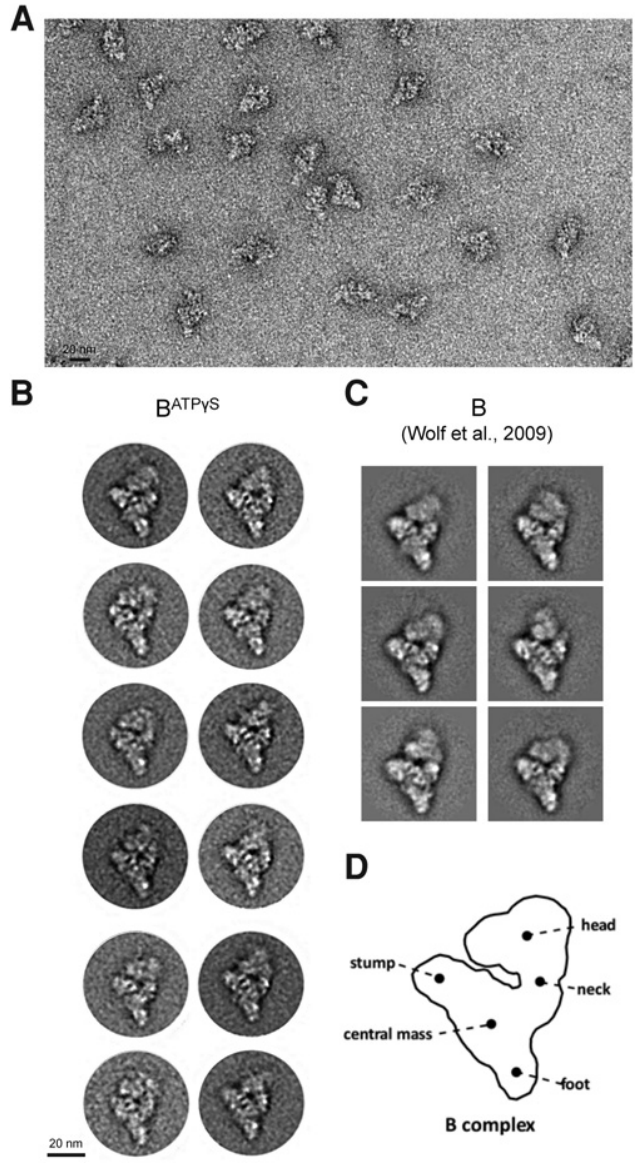

FIGURE 4. Electron microscopy of affinity-purified $B^{A T P} \gamma \mathrm{S}$ complexes. (A) Overview of negatively stained $\mathrm{B}^{\mathrm{ATP} \gamma \mathrm{S}}$ complexes. (B) Gallery of class averages of $\mathrm{B}^{\mathrm{ATP} \gamma \mathrm{S}}$ complexes. $(C)$ Typical class averages of $\mathrm{B}$ complexes purified after 6 min of splicing in the presence of ATP (Wolf et al. 2009). (D) Schematic representation of the human B complex, with main structural features labeled.

factors hPrp31 and hPrp6 are phosphorylated by hPrp4 kinase at this stage and these post-translational modifications were also proposed to potentially contribute to stable trisnRNP association during B complex formation (Schneider et al. 2010). Thus, one or more of these enzymes may require ATP $\gamma$ S concentrations above $0.25 \mathrm{mM}$ to allow efficient B complex formation.

Like the DEAD-box proteins Sub2 and hPrp5, hPrp28 may not require rapid ATP hydrolysis for its function during splicing. However, in the presence of an ATPase deficient hPrp28 mutant, 37S human pre-B complexes accumulate (Boesler et al. 2016). The latter contain the U4/U6.U5 trisnRNP, in addition to U1 and U2, but in contrast to B complexes, the tri-snRNP is not stably associated. Our data indicate, however, that the block in spliceosome assembly at low $\mathrm{ATP} \gamma \mathrm{S}$ concentrations occurs prior to the pre-B complex stage, as the vast majority of complexes that accumulate do not contain the tri-snRNP (Fig. 2). Thus, the block during the A to B complex transition must occur prior to the initial recruitment of the tri-snRNP.
As $\mathrm{B}^{\mathrm{ATP} \gamma \mathrm{S}}$ complexes contain stoichiometric amounts of U4 snRNA (Fig. 3), ATP $\gamma$ S clearly blocks the transition from a $\mathrm{B}$ complex to a $\mathrm{B}^{\text {act }}$ complex during the activation stage, which is initiated by loss/destabilization of the U4 snRNA due to Brr2-mediated unwinding of the U4/U6 duplex present in the B complex. Our purified $\mathrm{B}^{\mathrm{ATP} \gamma \mathrm{S}}$ complexes were also nearly devoid of the U1 snRNA (Fig. 3), suggesting that $\operatorname{Prp} 28$ has already facilitated the displacement of $\mathrm{U} 1$ from the 5 'ss, leading to the base-pairing interaction between the U6 snRNA ACAGA box and intron nucleotides near the $5^{\prime}$ ss. Thus, the action of these two spliceosomal helicases can apparently be uncoupled. The B complexes formed in the presence of ATP $\gamma S$ do not appear to be compositionally or structurally compromised. Thus, ATP $\gamma S$ most likely acts by inhibiting an enzyme required during the earliest stages of activation, most probably the ATP-dependent DEIH box RNA helicase Brr2. Indeed, previous studies have shown that Brr2 cannot use ATP $\gamma S$ for unwinding a U4/U6 duplex in vitro (Laggerbauer et al. 1998; Raghunathan and Guthrie 1998).

Small molecule inhibitors of splicing have proven to be valuable tools to study spliceosome assembly and function. To generate high-resolution structures of compositionally and conformationally dynamic, large (several MDa) ensembles such as the spliceosome, a major challenge is to obtain complexes that are biochemically and conformationally homogeneous. Our data show that ATP $\gamma S$ is an important tool to obtain more homogeneous B complexes, which are nearly devoid of Prp19 complex and Prp19-related proteins. This contrasts with those B complexes stalled by other small molecule inhibitors, such as SAHA and DHC (Kuhn et al. 2009). $B^{\text {ATP } \gamma S}$ complexes thus may prove highly useful for both functional and structural analyses of the precatalytic spliceosome, as well as its conversion into an activated $\mathrm{B}^{\text {act }}$ spliceosomal complex.

\section{MATERIALS AND METHODS}

\section{In vitro splicing and analysis of splicing complex formation}

Uniformly $\left[{ }^{32} \mathrm{P}\right]$-labeled, $\mathrm{m}^{7} \mathrm{G}\left(5^{\prime}\right) \mathrm{ppp}\left(5^{\prime}\right) \mathrm{G}$-capped MINX premRNA was synthesized in vitro by T7 runoff transcription and gel purified. HeLa nuclear extract was prepared essentially as previously described (Dignam et al. 1983). Nuclear extract was depleted of ATP by incubating in the presence of $2 \mathrm{mM}$ glucose for $30 \mathrm{~min}$ at $30^{\circ} \mathrm{C}$ (Michaud and Reed 1991). A typical splicing reaction contained 10 $\mathrm{nM}$ of ${ }^{32} \mathrm{P}$-labeled pre-mRNA and $40 \%$ HeLa nuclear extract in buffer containing $3 \mathrm{mM} \mathrm{MgCl}_{2}, 65 \mathrm{mM} \mathrm{KCl}, 20 \mathrm{mM}$ HEPES-KOH pH 7.9, $2 \mathrm{mM}$ ATP, and $20 \mathrm{mM}$ creatine phosphate and was incubated at $30^{\circ} \mathrm{C}$ for the times indicated. Alternatively, instead of adding ATP and creatine phosphate, the reactions were supplemented with 0.25 to $4 \mathrm{mM} \mathrm{ATP} \gamma \mathrm{S}$ or $2 \mathrm{mM}$ AMP-PNP. RNA was then isolated and analyzed by denaturing PAGE on a $6 \mathrm{M}$ urea, $14 \%$ polyacrylamide gel, followed by autoradiography. Spliceosomal complexes were analyzed by agarose gel electrophoresis in the presence 
of $0.65 \mu \mathrm{g} / \mu \mathrm{L}$ heparin (Das and Reed 1999) and bands were visualized with a Typhoon phosphoimager (GE Healthcare).

\section{MS2 affinity selection of splicing complexes}

Spliceosomal complexes were isolated by MS2 affinity selection. Briefly, MINX pre-mRNA containing three MS2 aptamers at its $3^{\prime}$ end was incubated with a 15-fold molar excess of MS2-MBP fusion protein and then added to a splicing reaction lacking ATP but supplemented with ATP $\gamma$ S. After incubating at $30^{\circ} \mathrm{C}$ for $180 \mathrm{~min}$ and centrifuging to remove aggregates, the reaction was loaded onto a MBP Trap HP column (GE Healthcare) after adding $100 \mathrm{mM}$ $\mathrm{NaCl}$. The column was washed with G-150 buffer $(20 \mathrm{mM}$ HEPES-KOH pH 7.9, $1.5 \mathrm{mM} \mathrm{MgCl}_{2}, 150 \mathrm{mM} \mathrm{NaCl}$ ) and complexes were eluted with G-150 buffer containing $1 \mathrm{mM}$ maltose. Eluted complexes were loaded onto a $14 \mathrm{~mL}$ linear $10 \%-30 \%(\mathrm{v} / \mathrm{v})$ glycerol gradient containing G-150 buffer, centrifuged at 25,000 rpm for 15 $\mathrm{h}$ at $4^{\circ} \mathrm{C}$ in a Sorvall TST 41.14 rotor and fractions were harvested from the bottom. The distribution of ${ }^{32} \mathrm{P}$-labeled MINX RNA across the gradient was determined by Cherenkov counting. Peak fractions containing the spliceosomal complexes were pooled, and their RNA and protein compositions determined by denaturing PAGE and 2D gel electrophoresis, respectively.

\section{D gel electrophoresis and mass spectrometry}

Two-dimensional gel electrophoresis of affinity-purified spliceosomal complexes was performed as described in Agafonov et al. (2011). For mass spectrometry, Coomassie-stained protein spots were cut out of the 2D gel and proteins were digested in-gel with trypsin and extracted. The extracted peptides were analyzed in a liquid chromatography coupled electrospray ionization quadrupole time of flight mass spectrometer (LTQ Orbitrap XL) under standard conditions. Proteins were identified by searching fragment spectra against the NCBI nonredundant (nr) database using Mascot as a search engine.

\section{Electron microscopy}

Purified spliceosomal complexes were loaded onto a 10\%-30\% (v/ v) glycerol gradient in buffer G150 containing a linear gradient of 0\%-0.1\% glutaraldehyde (GraFix method) (Kastner et al. 2008). After centrifugation for $1: 47 \mathrm{~h}$ at $60,000 \mathrm{rpm}$ in a TH660 rotor, the gradient was harvested from the bottom in $120 \mu \mathrm{L}$ fractions. Particles in peak gradient fractions were negatively stained with uranyl formate by the single-carbon film method adopted from Golas et al. (2003). Images were recorded using a CM 200-FEG electron microscope (FEI) at a magnification of $115,000 \times$ with a $4 \mathrm{k} \times 4 \mathrm{k}$ digital camera (TVIPS). After performance of a reference-free alignment procedure (Dube et al. 1993), images were subjected to multivariate statistical analysis (MSA) and classification (van Heel and Frank 1981; van Heel 1984; Dube et al. 1993). The resulting class averages were used as reference images in subsequent rounds of alignment until the class averages were stable.

\section{ACKNOWLEDGMENTS}

We are grateful to T. Conrad for cultivation of HeLa cells. We thank I. Öchsner, U. Plessmann, M. Raabe, and H. Kohansal for excellent technical assistance. This work was supported by a grant (LU294/151) from the Deutsche Forschungsgemeinschaft (DFG) to R.L.

Received June 14, 2016; accepted June 28, 2016.

\section{REFERENCES}

Agafonov DE, Deckert J, Wolf E, Odenwalder P, Bessonov S, Will CL, Urlaub H, Lührmann R. 2011. Semiquantitative proteomic analysis of the human spliceosome via a novel two-dimensional gel electrophoresis method. Mol Cell Biol 31: 2667-2682.

Berg MG, Wan L, Younis I, Diem MD, Soo M, Wang C, Dreyfuss G. 2012. A quantitative high-throughput in vitro splicing assay identifies inhibitors of spliceosome catalysis. Mol Cell Biol 32: 1271-1283.

Bessonov S, Anokhina M, Krasauskas A, Golas MM, Sander B, Will CL, Urlaub H, Stark H, Lührmann R. 2010. Characterization of purified human $\mathrm{B}^{\text {act }}$ spliceosomal complexes reveals compositional and morphological changes during spliceosome activation and first step catalysis. RNA 16: 2384-2403.

Boesler C, Rigo N, Anokhina MM, Tauchert MJ, Agafonov DE, Kastner B, Urlaub H, Ficner R, Will CL, Lührmann R. 2016. A novel spliceosome intermediate with loosely-associated tri-snRNP accumulates in the absence of Prp28 ATPase activity. Nat Commun 7: 11997.

Cao W, Jamison SF, Garcia-Blanco MA. 1997. Both phosphorylation and dephosphorylation of ASF/SF2 are required for pre-mRNA splicing in vitro. RNA 3: 1456-1467.

Cordin O, Beggs JD. 2013. RNA helicases in splicing. RNA Biol 10: 83-95.

Das R, Reed R. 1999. Resolution of the mammalian E complex and the ATP-dependent spliceosomal complexes on native agarose minigels. RNA 5: 1504-1508.

Dignam JD, Lebovitz RM, Roeder RG. 1983. Accurate transcription initiation by RNA polymerase II in a soluble extract from isolated mammalian nuclei. Nucleic Acids Res 11: 1475-1489.

Dube P, Tavares P, Lurz R, van Heel M. 1993. The portal protein of bacteriophage SPP1: a DNA pump with 13-fold symmetry. EMBO J 12: 1303-1309.

Effenberger KA, Perriman RJ, Bray WM, Lokey RS, Ares M Jr, Jurica MS. 2013. A high-throughput splicing assay identifies new classes of inhibitors of human and yeast spliceosomes. J Biomol Screen 18: $1110-1120$.

Effenberger KA, James RC, Urabe VK, Dickey BJ, Linington RG, Jurica MS. 2015. The natural product N-palmitoyl-1-leucine selectively inhibits late assembly of human spliceosomes. J Biol Chem 290: 27524-27531.

Golas MM, Sander B, Will CL, Lührmann R, Stark H. 2003. Molecular architecture of the multiprotein splicing factor SF3b. Science 300: 980-984.

Kastner B, Fischer N, Golas MM, Sander B, Dube P, Boehringer D, Hartmuth K, Deckert J, Hauer F, Wolf E, et al. 2008. GraFix: sample preparation for single-particle electron cryomicroscopy. Nat Methods 5: 53-55.

Kim SH, Lin RJ. 1996. Spliceosome activation by PRP2 ATPase prior to the first transesterification reaction of pre-mRNA splicing. Mol Cell Biol 16: 6810-6819.

Kuhn AN, van Santen MA, Schwienhorst A, Urlaub H, Lührmann R. 2009. Stalling of spliceosome assembly at distinct stages by smallmolecule inhibitors of protein acetylation and deacetylation. $R N A$ 15: $153-175$.

Laggerbauer B, Achsel T, Lührmann R. 1998. The human U5-200kD DEXH-box protein unwinds U4/U6 RNA duplices in vitro. Proc Natl Acad Sci 95: 4188-4192.

Lardelli RM, Thompson JX, Yates JR III, Stevens SW. 2010. Release of SF3 from the intron branchpoint activates the first step of premRNA splicing. RNA 16: 516-528.

Li HC, Simonelli PF, Huan LJ. 1988. Preparation of protein phosphatase-resistant substrates using adenosine $5^{\prime}-\mathrm{O}-(\gamma$-thio)triphosphate. Methods Enzymol 159: 346-356. 
Liu YC, Cheng SC. 2015. Functional roles of DExD/H-box RNA helicases in pre-mRNA splicing. J Biomed Sci 22: 54.

Makarova OV, Makarov EM, Urlaub H, Will CL, Gentzel M, Wilm M, Lührmann R. 2004. A subset of human 35 S U5 proteins, including Prp19, function prior to catalytic step 1 of splicing. EMBO J 23: 2381-2391.

Mathew R, Hartmuth K, Mohlmann S, Urlaub H, Ficner R, Lührmann R. 2008. Phosphorylation of human PRP28 by SRPK2 is required for integration of the U4/U6-U5 tri-snRNP into the spliceosome. Nat Struct Mol Biol 15: 435-443.

Mermoud JE, Cohen P, Lamond AI. 1992. Ser/Thr-specific protein phosphatases are required for both catalytic steps of pre-mRNA splicing. Nucleic Acids Res 20: 5263-5269.

Mermoud JE, Cohen PT, Lamond AI. 1994. Regulation of mammalian spliceosome assembly by a protein phosphorylation mechanism. EMBO J 13: 5679-5688.

Michaud S, Reed R. 1991. An ATP-independent complex commits premRNA to the mammalian spliceosome assembly pathway. Genes Dev 5: 2534-2546.

Misteli T. 1999. RNA splicing: what has phosphorylation got to do with it? Curr Biol 9: 198-200.

Pawallek A, McElroy S, Samatov T, Mitchell L, Woodland A, Ryder U, Gray D, Lührmann R, Lamond AI. 2015. Identification of small molecule inhibitors of pre-mRNA splicing. J Biol Chem 289: 34683-34698.

Raghunathan PL, Guthrie C. 1998. RNA unwinding in U4/U6 snRNPs requires ATP hydrolysis and the DEIH-box splicing factor Brr2. Curr Biol 8: 847-855.

Schneider M, Hsiao HH, Will CL, Giet R, Urlaub H, Lührmann R. 2010. Human PRP4 kinase is required for stable tri-snRNP association during spliceosomal B complex formation. Nat Struct Mol Biol 17: 216-221.

Shi Y, Reddy B, Manley JL. 2006. PP1/PP2A phosphatases are required for the second step of pre-mRNA splicing and target specific snRNP proteins. Mol Cell 23: 819-829.

Soret J, Tazi J. 2003. Phosphorylation-dependent control of the premRNA splicing machinery. Prog Mol Subcell Biol 31: 89-126.

Staley JP, Guthrie C. 1998. Mechanical devices of the spliceosome: motors, clocks, springs, and things. Cell 92: 315-326.
Staley JP, Guthrie C. 1999. An RNA switch at the 5' splice site requires ATP and the DEAD box protein Prp28p. Mol Cell 3: 55-64.

Tazi J, Daugeron MC, Cathala G, Brunel C, Jeanteur P. 1992. Adenosine phosphorothioates (ATPaS and ATP $\tau$ S) differentially affect the two steps of mammalian pre-mRNA splicing. I Biol Chem 267: $4322-4326$.

Tazi J, Kornstädt U, Rossi F, Jeanteur P, Cathala G, Brunel C, Lührmann R. 1993. Thiophosphorylation of U1-70K protein inhibits pre-mRNA splicing. Nature 363: 283-286.

Valadkhan S. 2013. The role of snRNAs in spliceosomal catalysis. Prog Mol Biol Transl Sci 120: 195-228.

van Heel M. 1984. Multivariate statistical classification of noisy images (randomly oriented biological macromolecules). Ultramicroscopy 13: $165-183$.

van Heel M, Frank J. 1981. Use of multivariate statistics in analysing the images of biological macromolecules. Ultramicroscopy 6: 187194.

Wahl MC, Lührmann R. 2015. Spliceosome dynamics I. Cell 161: 1474.

Wahl MC, Will CL, Lührmann R. 2009. The spliceosome: design principles of a dynamic RNP machine. Cell 136: 701-718.

Warkocki Z, Odenwälder P, Schmitzová J, Platzmann F, Stark H, Urlaub H, Ficner R, Fabrizio P, Lührmann R. 2009. Reconstitution of both steps of Saccharomyces cerevisiae splicing with purified spliceosomal components. Nat Struct Mol Biol 16: 1237-1243.

Will CL, Lührmann R. 2011. Spliceosome structure and function. Cold Spring Harb Perspect Biol 3: a003707.

Wolf E, Kastner B, Deckert J, Merz C, Stark H, Lührmann R. 2009. Exon, intron and splice site locations in the spliceosomal B complex. EMBO J 28: 2283-2292.

Xiao SH, Manley JL. 1997. Phosphorylation of the ASF/SF2 RS domain affects both protein-protein and protein-RNA interactions and is necessary for splicing. Genes Dev 11: 334-344.

Yount RG. 1975. ATP analogs. Adv Enzymol Relat Areas Mol Biol 43: $1-56$.

Zhou Z, Fu X-D. 2013. Regulation of splicing by SR proteins and SR protein-specific kinases. Chromosoma 122: 191-207.

Zhou A, Ou AC, Cho A, Benz EJ Jr, Huang SC. 2008. Novel splicing factor RBM25 modulates Bcl-x pre-mRNA 5' splice site selection. Mol Cell Biol 28: 5924-5936. 

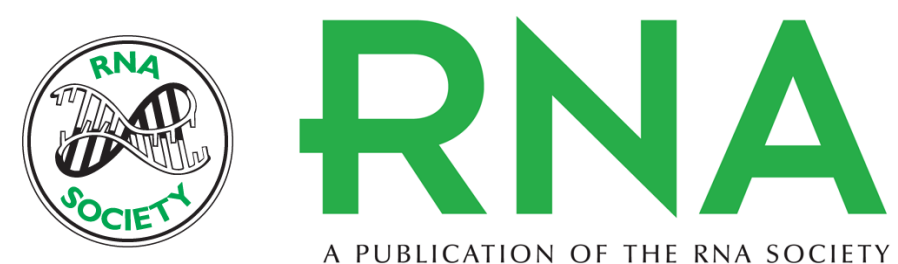

A PUBLICATION OF THE RNA SOCIETY

\section{ATP $\gamma$ stalls splicing after B complex formation but prior to spliceosome activation}

Dmitry E. Agafonov, Marieke van Santen, Berthold Kastner, et al.

RNA 2016 22: 1329-1337 originally published online July 13, 2016

Access the most recent version at doi:10.1261/rna.057810.116

References This article cites 46 articles, 18 of which can be accessed free at: http://rnajournal.cshlp.org/content/22/9/1329.full.html\#ref-list-1

Creative This article is distributed exclusively by the RNA Society for the first 12 months after the Commons full-issue publication date (see http://rnajournal.cshlp.org/site/misc/terms.xhtml). After 12 License months, it is available under a Creative Commons License (Attribution-NonCommercial 4.0 International), as described at http://creativecommons.org/licenses/by-nc/4.0/.

Email Alerting Receive free email alerts when new articles cite this article - sign up in the box at the Service top right corner of the article or click here. 